\title{
A PLACE OF MIRACLES. THE ARTISTIC REPRESENTATION OF LOURDES BY TWO CONTEMPORARY DIRECTORS: \\ LOURDES (2009) BY JESSICA HAUSNER AND UNE FEMME NOMMÉE MARIE (2011) BY ROBERT HOSSEIN
}

\author{
Theo Meder
}

\begin{abstract}
After the Holy Virgin had appeared eighteen times to Bernadette Soubirous in 1858, Lourdes in the south of France grew into the most popular and most visited place of pilgrimage in the western Christian world. Today millions of pilgrims come to Lourdes each year for various religious reasons. Quite a few of them suffer from a physical or mental illness. One of the reasons why they come to Lourdes is the possibility of a miraculous healing, for instance by drinking the healing water of Lourdes, or even bathing in it. Recently, two directors created works of art about and at the holy place of Lourdes, which reflect their convictions concerning miracles and healings. In 2009 the young female Austrian director Jessica Hausner shot her French movie Lourdes, in 2011 the renowned French male director Robert Hossein presented his spectacle Une femme nommée Marie. Jessica Hausner was raised in a Catholic family, but lost her faith and became an atheist, whereas Robert Hossein grew up in an atheist family and converted to Catholicism later in life. Their works offer rather opposite interpretations of (Christian) conceptions such as supernatural healings and salvation.
\end{abstract}

Keywords: miracle, legend, belief, movie, play

\section{INTRODUCTION}

The most famous, and most visited, place of pilgrimage in the Christian Western world is Lourdes, situated in the Hautes-Pyrénées department in southwestern France. ${ }^{1}$ To some, it is a miraculous place of grace, to others, it is "Catholic Disneyland". ${ }^{2}$ Lourdes developed into a place of pilgrimage after the Holy Virgin Mary had allegedly appeared up to eighteen times before the simple miller's daughter Bernadette Soubirous (1844-1879) in 1858. Lourdes saw the construction of a sanctuary, which has been visited by approximately two hun- 
dred million pilgrims since 1860. Nowadays the place of pilgrimage is visited by some six million pilgrims on an annual basis, not just from neighboring European countries but from distant Asian countries like the Philippines and South Korea as well. Lourdes owes much of its fame to the miraculous healings, which have occurred from the very beginning. The water of Lourdes is attributed with healing qualities. On the grounds of the Sanctuary, it can be used for drinking as well as for bathing. In total, sixty-seven miraculous healings have been officially acknowledged by the Roman Catholic Church.

Lourdes has repeatedly been used as an artistic topic. The French writer Émile Zola (1840-1902) wrote a sceptical novel entitled Lourdes about the healing of Marie de Guersaint. Even more famous is probably the testimonial novel Das Lied von Bernadette by the Austrian author Franz Werfel (1890-1945), published in 1941. In 1943, this book was adapted for the screen in the USA under the title The Song of Bernadette. A French version of the girl's testimony was filmed under the title Bernadette in 1988 by Jean Delannoy. Very recently, another two directors decided to stage major productions around the theme of Lourdes, the miracle place. In 2009, the Austrian director Jessica Haus-

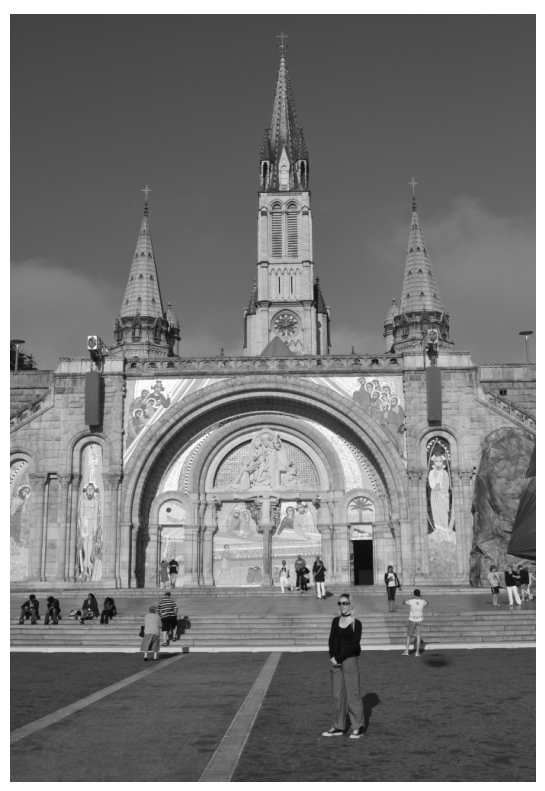

Figure 1. The Basilica of our Lady of the Rosary.

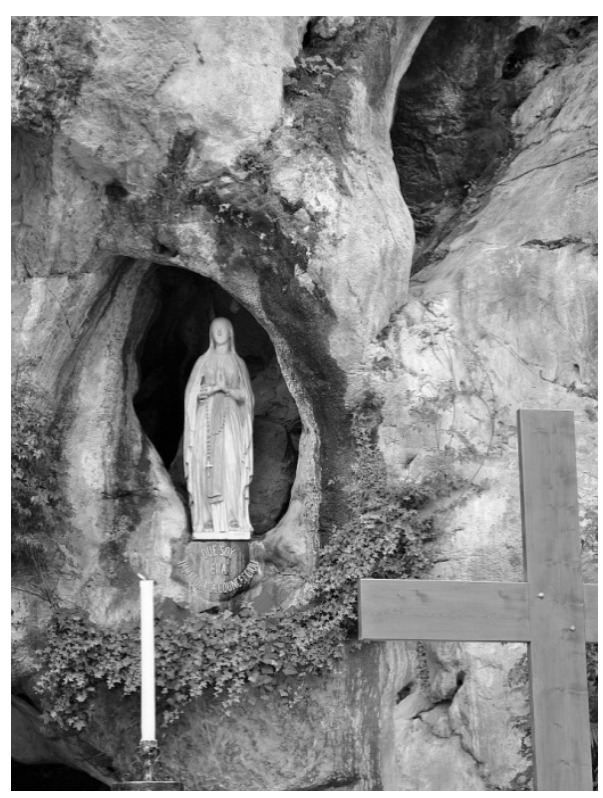

Figure 2 The Grotto of Massabielle with the statue of the Virgin Mary in Lourdes. Photos: Theo Meder 2011. 


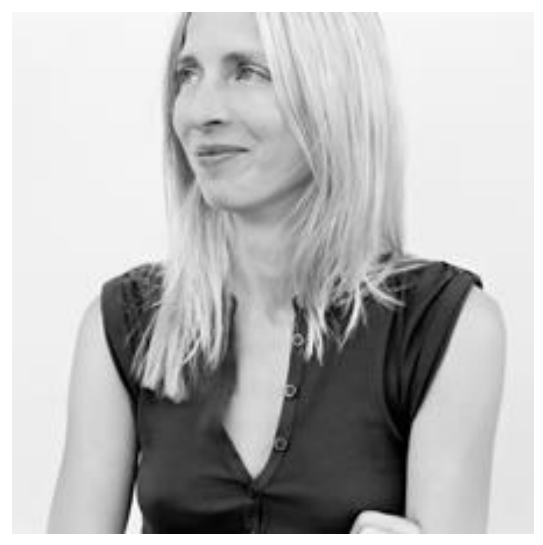

Figure 3. Jessica Hausner.

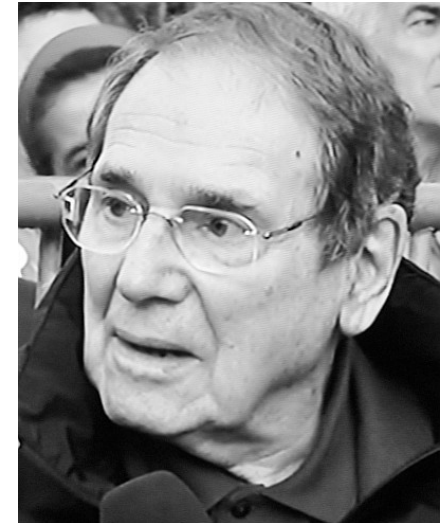

Figure 4 Robert Hossein

ner completed her (French-language) film Lourdes, which was not shown in most countries until 2010, and which was notably successful in the art-house circuit. In 2011, the French director Robert Hossein staged the showpiece Une femme nommée Marie, which was performed once in Lourdes, on 13 August, the Saturday preceding the Assumption of Mary (August 15).

In this paper, I intend to confront the two aforementioned contemporary works of art. This could be of particular interest, given the rather contrasting position their two creators find themselves in. To begin with, Hausner is a woman and Hossein is a man. Secondly, Hausner was born in 1972 and Hossein in 1927. So at the premieres of their pieces, the directors were thirty-eight and eighty-three years of age, respectively. As far as age is concerned, the two directors clearly represent two entirely different generations. Perhaps most important, though, is the following fact: Jessica Hausner grew up in a Catholic environment, but renounced her faith at an early stage. She is now an avowed atheist (who calls herself an agnostic in her milder moments). ${ }^{3}$ Robert Hossein, conversely, was raised as an atheist, but converted to Catholicism later in life.

Below I will first discuss the content of the two artistic pieces, in chronological order, i.e. first the film Lourdes by Jessica Hausner, followed by the outdoor theatre spectacle Une femme nommée Marie by Robert Hossein. I will then confront the different approaches applied in the two pieces and finish by drawing my conclusions on the contemporary perspective on Lourdes as a place of miracles by two contemporary artists. 


\section{THE FILM LOURDES}

In some respects, the film Lourdes by Jessica Hausner resembles a documentary. It tells the fictitious story of a single young woman called Christine (played by the French actress Sylvie Testud), who goes on a pilgrimage to Lourdes in the company of several other pilgrims, some of whom are ill. Suffering from multiple sclerosis, Christine is paralysed from the neck down and in constant need of nursing care. She would have preferred to go on a cultural trip (to Rome, for instance), but, faced with her need of permanent care, she has chosen to go to Lourdes, which is much more wheelchair-friendly. In actual fact, Christine is hardly religious, if at all. Contrary to many of the others in the group, she has not come to Lourdes hoping for a miraculous healing, even though she does experience her disability as a burden.

The lively Maria (played by Léa Seydoux) has been assigned as Christine's special nurse. Maria registered as a volunteer with the Order of Malta, an order of Knight Hospitallers. She pushes Christine's wheelchair, feeds her during meals and helps her to bed. Maria claims to have volunteered to add a sense of meaning to her life, but it soon becomes clear that she is more interested in the handsome Order Knight Kuno (played by Bruno Todeschini) than in caring for people. Consequently, she often neglects her duties towards Christine.

Christine's roommate, a pious and silent elderly woman named Mrs Hartl (played by Gilette Barbier) - who is lonely, though not ill - is happy to take over the duties of the flirting nurse, whenever necessary. The first time Christine is taken into the grotto by nurse Maria, she is not even capable of

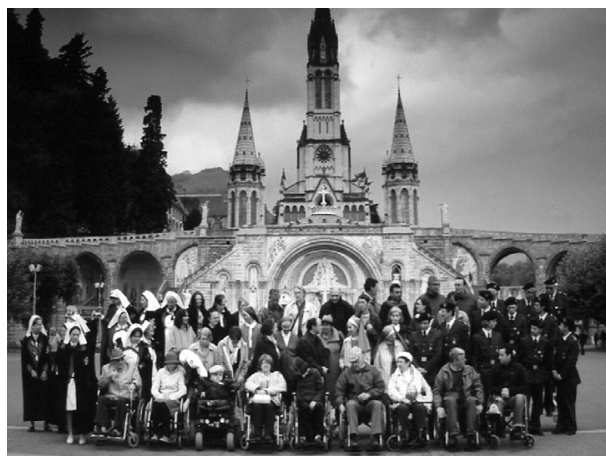

Figure 5. Group photo (still from Lourdes).

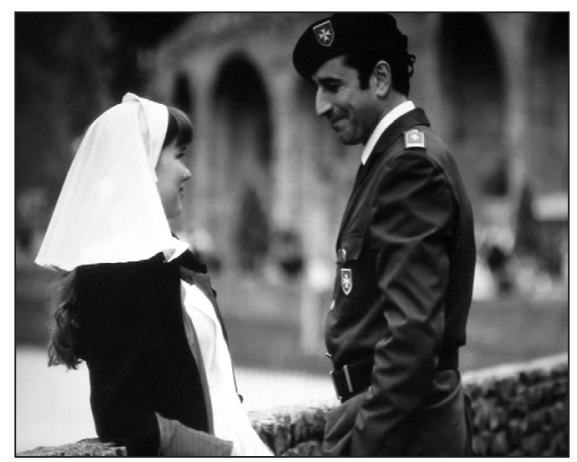

Figure 6. Maria flirting with Kuno (still from Lourdes) 
lifting her hand to touch the cave wall. The nurse has to guide it. Next she is bathed in the therapeutic holy water. When she goes to the cave for the second time, she is being pushed by Mrs Hartl. At this point, Christine can lift her hand enough to touch the wall without help. Unfortunately, nobody notices. At one of the masses, Mrs Hartl pushes Christine all the way to the front of the church, which will cost them a reprimand from group leader Cécile (Elina Löwensohn): they should not imagine that jumping the queue will precipitate the healing process. Remarkably enough, both Christine and Cécile have a predictive dream one night, featuring the Holy Virgin Mary, enabling crippled Christine to get up from her wheelchair. Cécile would clearly find this unfair. She is herself terminally ill, and being a much more devout Catholic than Christine, she would be the more rightful recipient of a miraculous cure. But apparently, this is not how it works.

For in the middle of the night, Christine wakes up. She sits up in bed, gets out, walks to the bathroom and starts combing her hair. She then dresses herself. The following morning, she ostentatiously gets up from her wheelchair, to the amazement of the nurse. From now on, she can eat her own breakfast. All of a sudden, Christine becomes the centre of attention - albeit that some pilgrims can barely hide their envy. The group photo in front of the basilica, for instance, must be retaken, now to be gathered round the chosen girl who got up from her wheelchair. Father Nigl, the priest accompanying the group (played by Gerhard Liebmann), takes her to the doctor of the place of pilgrimage to find out if the healing could be acclaimed as a miracle. The doctor appears reluctant: sudden recoveries are not uncommon in multiple sclerosis, but tend to remain temporary. Medically speaking, these need not be indicative of any miracle. For all that, Christine gets a walking stick and no longer needs her wheelchair. Some time later, when she is having an ice cream sundae at an outdoor café, all the waiters gather round to give her a big hand in honour of the latest miracle. Much to the annoyance of nurse Maria, Order Knight Kuno is also beginning to take an interest in Christine: at an outing to the Pic du Jer (a funicular railway at the Pyrenees' summit closest to Lourdes) with all the other pilgrims, he even kisses her in secret and tells her she is "very special".

The pilgrimage concludes with a dancing party. Christine is presented the "Best Pilgrim Award", a small statue of the Virgin Mary. But while Kuno and Christine are dancing, Christine suddenly falls to the ground. Has she just stumbled or has her disease regained power? Christine allows the others to help her up. Smiling at first, she says it was just an accident. She does, however, lean against the wall to stay on her feet. Meanwhile, doubts about the miracle start spreading. After all, temporary miracles are no acknowledged miracles. 
Theo Meder

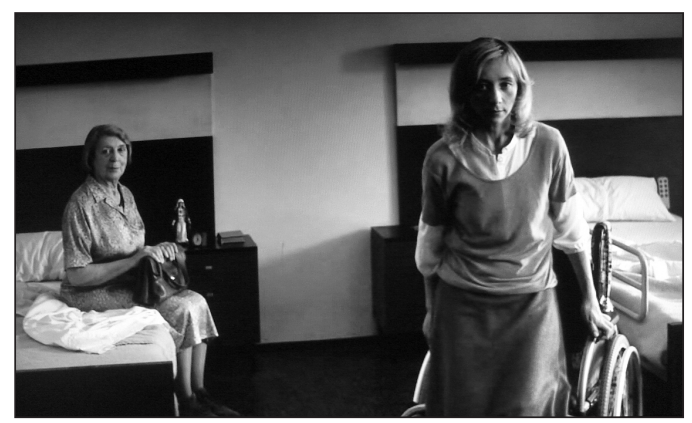

Figure 7. Christine getting up from her wheelchair (still from Lourdes).

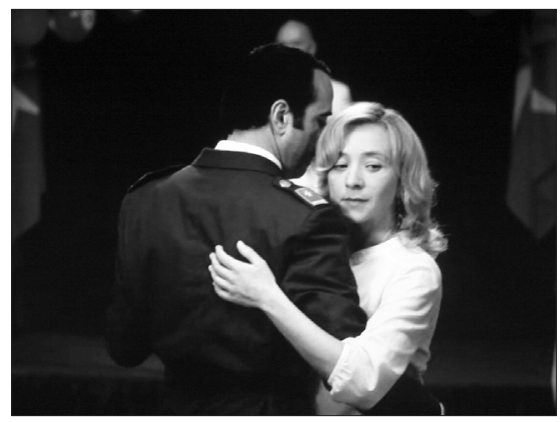

Figure 8. Christine dancing with Kuno (still from Lourdes).

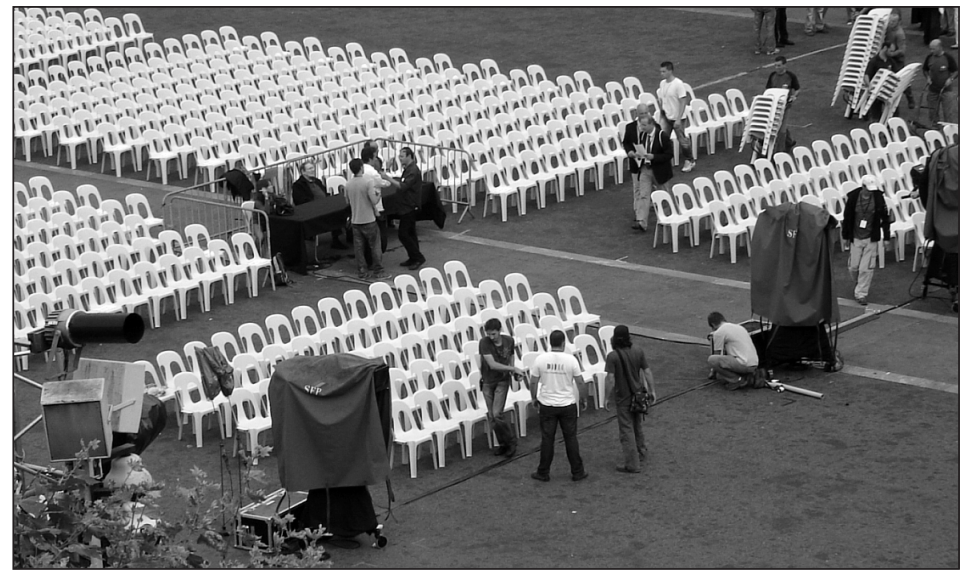

Figure 9. Preparations being made in Lourdes for the performance of Une femme nommée Marie. Director Robert Hossein is sitting in the middle, behind the black table. Photo: Theo Meder 2011. 
Two women from the group wonder in despair if God can withdraw a miracle just like that, and if $\mathrm{He}$ is actually in charge. And if not, who is? But their attention soon averts to an entirely different (and apparently far more important) matter: "Do you think we'll be getting a dessert?" Mrs Hartl silently joins Christine, taking the wheelchair along. Christine tries to remain standing for a while, but finally decides to sit down. This is the point where the film reaches its open ending. What really happened and how it all ended remains a mystery to be solved by the viewer.

\section{THE OPEN-AIR PLAY UNE FEMME NOMMÉE MARIE}

The film Lourdes was filmed on location in Lourdes, with permission from the ecclesiastical authorities. The theatre spectacle Une femme nommée Marie was performed on the esplanade in front of the Rosary Basilica in Lourdes on 13 August 2011. A direct view of the stage was reserved for the sick and the VIPs invited by Robert Hossein. Others present in Lourdes could watch the performance on large screens. In total there were about twenty-five thousand viewers, including fifteen hundred sick persons. For the purpose of the performance, another large screen had been set up in the city centre of Paris, near the Notre Dame Cathedral. In addition, the national television channel France 3 presented a live broadcast of the show. ${ }^{4}$

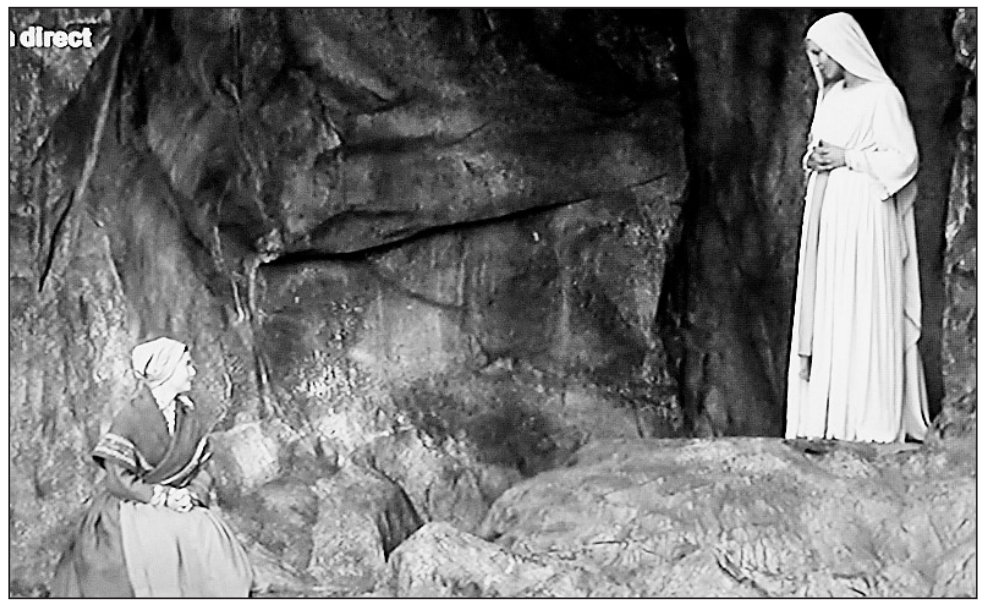

Figure 10. The Virgin Mary appearing to Bernadette Soubirous (still from Une femme nommée Marie). 


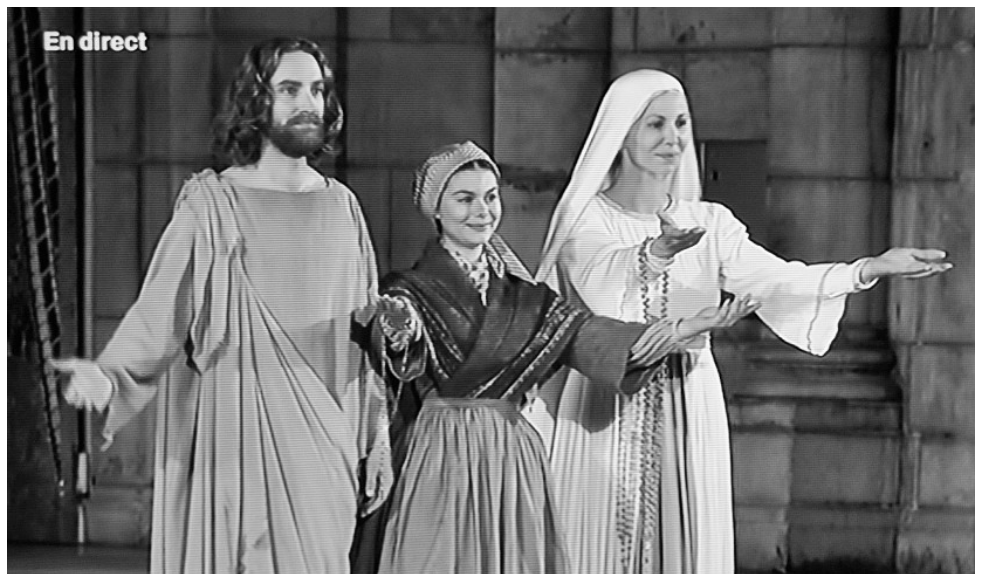

Figure 11. Jesus, Bernadette and Mary (still from Une femme nommée Marie).

The central theme in this son et lumière performance ${ }^{5}$ is not some random contemporary miracle, but the very miracle that put Lourdes on the map: the apparition of the Virgin Mary in front of the simple girl Bernadette Soubirous, in the Grotto of Massabielle. In the usual version of the legend, Mary and Bernadette have several brief meetings, during which Mary primarily promotes the establishment of a sanctuary. Une femme nommée Marie deviates from this legend in the sense that Mary (played by Séverine Berthelot) decides to tell Bernadette (Manon Le Moal) the story of her Son Jesus (Pierre-Laurent Barnon). In a sequence of tableaux, accompanied by a profusion of dramatic music, we get to see many well-known biblical scenes, like Jesus being baptized by John the Baptist, the twelve Apostles joining Him, John the Baptist's beheading (at the request of Salome), Jesus curing the lepers and raising Lazarus from the dead, Jesus multiplying the bread, saving a sinful woman from being stoned to death, sharing the Last Supper with His disciples, being betrayed by Judas for thirty pieces of silver and being condemned to death while Pontius Pilate (played by journalist Henry-Jean Servat, Hossein's biographer) washes his hands in innocence. Jesus is subsequently mocked, given a crown of thorns, forced to bear His own cross and left to die on this cross for the sins of mankind. After His death, the Apostles spread the faith, which has lived on till this day. The piece ends with actors, dressed in classic and modern clothing, walking into the audience as evangelists handing out bottles of healing Lourdes water to the sick. At the final chords, Jesus reappears on stage to collect Bernadette and His mother Mary from the Lourdes grotto. 


\section{ANALYSIS AND CONFRONTATION}

Robert Hossein (Paris, France, 30 December 1927) has a substantial oeuvre to his name as an actor, writer and director, although he is mostly a celebrity in his own country. Most people will know him as the (scarfaced) husband of Angélique from the film series of the same name (1964-1968) by director Bernard Borderie. He played opposite Brigitte Bardot in the film Le repos du guerrier (1962) by Roger Vadim and in countless other productions, one of which being Les uns et les autres (1981) by Claude Lelouch (which was awarded a prize at the Cannes Film Festival). Hossein established his reputation as a director when he adapted Les Misérables for the screen (1982) and staged the showpiece Ben-Hur (2006). More recently, he directed plays like L'affaire Seznec (2010) and L'affaire Dominici (2010). Hossein made several religious spectacles about Jesus and about the Pope: Un homme nommé Jésus (1983), Jésus était son nom (1991), Jésus la résurrection (2000) and N'ayez pas peur! Jean-Paul II (2007). ${ }^{6}$

Robert Hossein was born in France from a mixed marriage. His father was originally from Uzbekistan, descending from a Persian family. His mother came from a Jewish family from Ukraine. With his parents not showing any interest in religion, Robert was in fact raised as an atheist ${ }^{7}$, although he did get acquainted with the Russian Orthodox Church as a child in his boarding school years (Hossein 1978: 28-29; Barthélémy 1987: 114). It was not until the 1970s that Robert Hossein converted to Catholicism. He was baptized along with his youngest son. ${ }^{8}$ Passing through on his way to the south of France in 2009, he visited Lourdes for the first time. Completely overwhelmed by the mere sight of it, he fell down and burst into tears (leaving his wife to think he was having a heart attack). His director's eye must have been drawn to the mosaics about Christ on the outside walls of the Rosary Basilica and to the possibilities offered by the steps and the raised platform, which might serve as a theatrical stage. The Esplanade in front of it would complete the ideal open-air theatre (Borde 2011b: 2; Servat 2011; Vayne 2011; Lebard 2011: 4). In his work, Robert Hossein often expresses his commiseration for the fate of his fellow man in general, and of the outcast in particular - his motivation for this being not so much political commitment, but rather religiously-inspired compassion. In actual fact, Hossein testifies to his religious conviction in Une femme nommée Marie. In doing so, he attempts to deliver the evangelical message of charity in particular. Focussing on the story of the Passion of the Christ, Hossein's piece stands in a long tradition, dating back as far as the Middle Ages (Vayne 2011). It goes without saying that the gospels cannot be dealt with in their entirety in barely two hours. This has clearly 
prompted Hossein to present a selection of scenes showing Jesus from His loving, merciful, charitable and sacrificial side. This image is further endorsed by selected quotes like "it is hard for a rich man to enter the kingdom of heaven" (Matthew 19: 23), "let he who is without sin cast the first stone" (John 8: 7) and "love thy neighbour as thyself" (Matthew 22: 39). In addition to this, Hossein intends to convince his audience of the truth of a religious mystery like the transsubstantiation of bread and wine into the body and blood of Christ in the scene of the Last Supper. All in all, Une femme nommée Marie must be considered as a testimonial piece by a converted Roman Catholic.

Jessica Hausner (Vienna, Austria, 6 October 1972) is an upcoming young talent, who has by now made three feature films: Lovely Rita from 2001, Hotel from 2004 and Lourdes from 2009. As her sources of inspiration for Lourdes, Hausner mentions the directors Carl Theodor Dreyer (who made the religious film Ordet in $1955^{9}$ ), Jacques Tati (because of his silent action and subtle humour) and Luis Buñuel (known for characteristic statements such as "Thank God I'm an atheist"). Critics occasionally add to this list by suggesting Alfred Hitchcock, on account of the suspense (which mainly applies to Hausner's film Hotel, which focusses on a mysterious disappearance).

Hausner's three feature films have two things in common: the open ending and the questions left unanswered. With each film, the viewer is deliberately left with the questions "What has happened exactly?" and "How will it end?". Each viewer is invited to fill in the gaps: was Christine's fall during the dance an incident or was it the foreboding of the return of her wasting disease? Will she retain her ability to walk or will she face a permanent return to her wheelchair? The following question will remain unanswered too: if the healing was only temporary, does that imply there was no miracle? An existential question that is asked but not answered in this film: if God is almighty and good, then why does He not simply heal everybody? The most important question that everyone, including Christine, asks in this film: why are some people chosen while others - who might deserve and wish for it more - are not? Why does God not hear those who are exceptionally pious and beg for healing wholeheartedly?

What is more, Hausner's Lourdes does not connive at the less pleasant traits of people, i.e. their pettiness and envy. A good example is the group's behaviour following Christine's resurrection from her wheelchair. All of a sudden, she becomes the centre of attention. Many of the people near her try to benefit from the situation by making eager attempts to catch a glimpse of the aura of the miracle. But as soon as the miracle ceases to be an actual miracle, attention is quick enough to start dwindling. Kuno, the kissing Order Knight, begins to feel awkward and decides to withdraw. If the miracle can no longer reflect on him, Christine thereby becomes dispensable. 


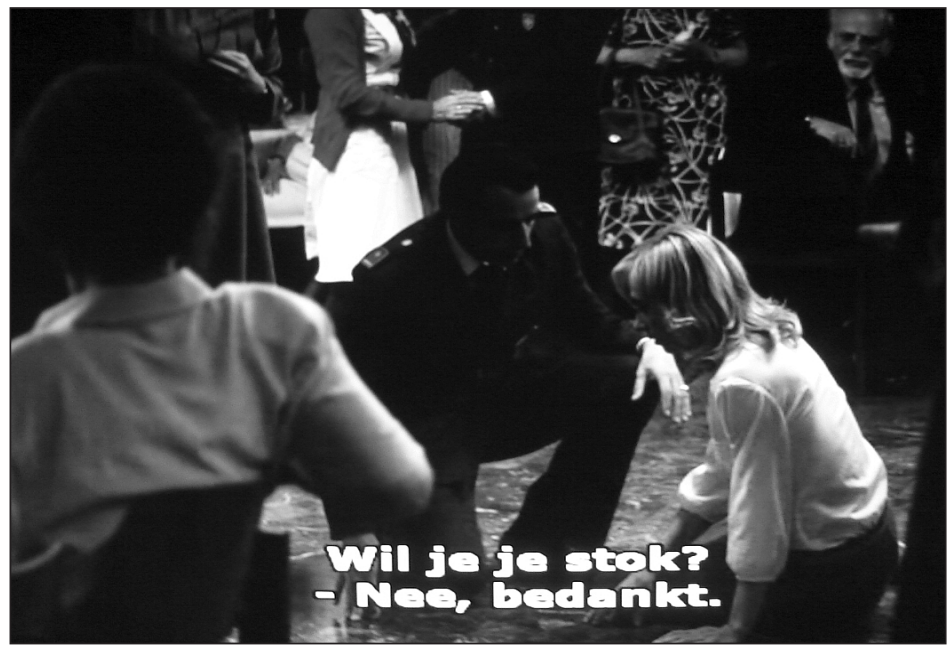

Figure 12. Christine falling down at the dance (still from Lourdes).

In spite of all, Lourdes should not be considered as an atheist, anti-Catholic or anti-religious film. It seriously examines, and consequently also problematizes, the phenomenon of the miracle. An American Jesuit who saw the film drew a surprising (and not entirely improbable) conclusion: the elderly Mrs Hartl, the silent, god-fearing, helpful roommate is God: she is all-seeing, allhearing, and always available (Martin 2010).

I must admit I find this an original interpretation, which the director never explicity mentions (nor may have intended), but which the film does not seem to oppose either. Personally, I would rather be inclined to see Mrs Hartl as the Virgin Mary. She does her good works incognito, has deep-rooted religious convictions, is patient and helpful - for better or for worse - and, above all, she is free of prejudice. There is one scene in the film that confirms me in this view more than any other. When we get a close-up of a smiling Mrs Hartl entering the scene, we can see behind her a white light on her right side and a large statue of the Virgin Mary to the left of her, suggesting she has just stepped off her pedestal. ${ }^{10}$

One review of Hausner's Lourdes contains the following justified observation: "Put a Catholic and an atheist in the same screening, and they'll see two different films" (Romney 2010). The film is balanced enough to appeal to both audiences. Having said that, it must be noted that the Catholic viewers have not come to a uniform opinion. On 3 March 2010, a certain JohnR posted an 


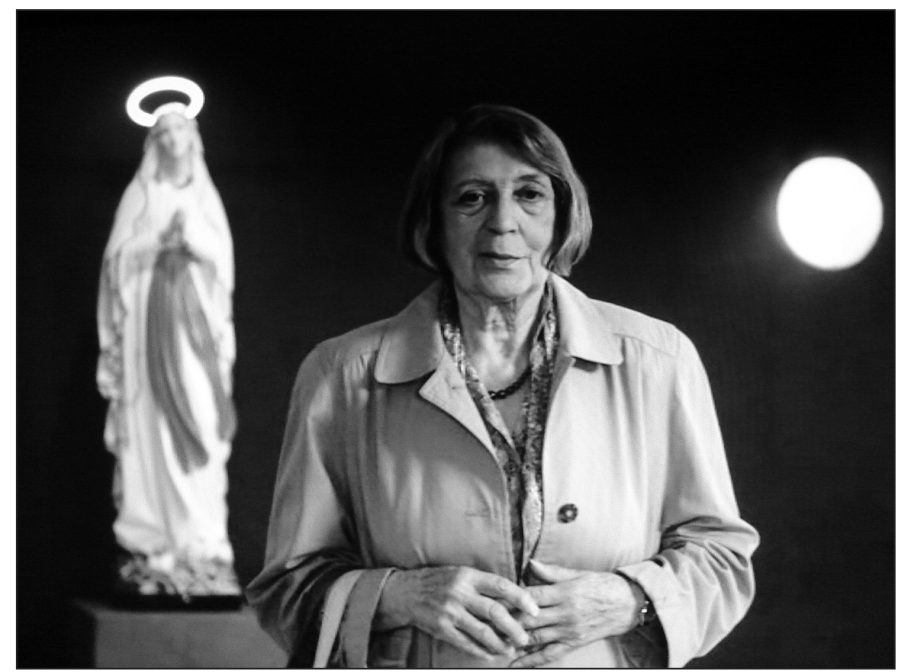

Figure 13. Mrs Hartl (still from Lourdes).

enthusiastic comment on a film forum: "As a Catholic, I wish more atheists would make such films!" (Film Forum Lourdes). The official Catholic response, however, tends to be somewhat more reserved. The film is said to lack the general atmosphere of love, gladness and affection that is believed to prevail among the volunteers, the sick and the pilgrims. The film is being accused of misrepresentation: the mood in Lourdes would not be this cold or distant, by far. ${ }^{11}$

The two pieces have in common two legend motifs, which have become quite closely associated with Lourdes as a place of miracles and a place of pilgrimage: the Marian apparition and the miraculous healing. In Hossein's piece, the apparition of Mary to Bernadette is the frame story: Mary tells the story of her Son to Bernadette. In Hausner's piece, Mary is present in a different way: Madonnas keep popping up, the charitable, helpful Mrs Hartl could be interpreted as the personification of Mary, or at least appears to assume some sort of Marian role. Furthermore, Mary acts as a mediator: miraculous healings in Lourdes are said to occur through her intercession. This brings us to the second central motif: the inexplicable and factually impossible healing, which, allegedly, could only be explained by divine intervention. In Hausner's film, Christine is healed after coming into contact with the Lourdes water. This young woman, who was paralysed from the neck down, regains control of her body in the following night. Another pilgrim from the group, a 
severely handicapped girl, is also beginning to respond to her mother's stimuli, which awaken her from her lethargy. Hossein's piece shows the true source of the miraculous power of healing: the humanity of God the Son and the omnipotence of God the Father. Jesus cured the lepers and even raised the leper Lazarus from the dead. Significantly, the show ends with the actors handing out bottles of Lourdes water to the sick in the front rows on the Esplanade. Hossein's piece opens the stage to a series of legends that are part of an age-long Catholic tradition and constitute the unshakeable truth of faith for the believers. Hausner's piece is in fact based on the same religious principle, with the difference that the director adds to it the introduction of the concept of doubt regarding the miracle. Is the healing really supernatural? If the cure is temporary, does that still make it a miracle? If God is behind it, why do the miracles seem so random? Why are some people cured, while others are not? Why does it not seem to matter how pious one is and how desperately one aspires to be healed? When God heals somebody miraculously, is it not cruel to see the miracle aborted after some time? If God is good and almighty, why does He not heal everybody? Or is He just good and not almighty, or, conversely, almighty, but not good? The severely handicapped daughter

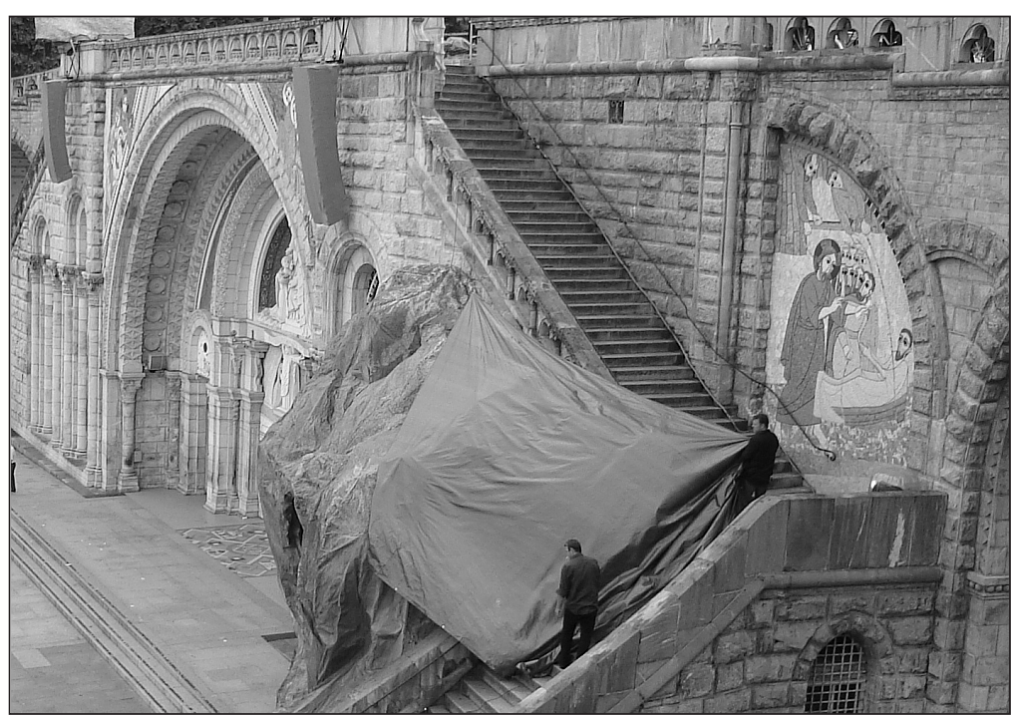

Figure 14. The cover of the stage grotto being removed for the performance of Une femme nommée Marie. Photo: Mereie de Jong 2011. 
soon reverts to her state of lethargy, and the persistence of Christine's cure is doubtful, to say the least.

\section{CONCLUSIONS}

Lourdes is the place of miracles that attracts a great deal of Catholics and other believers, in the form of pilgrims, seekers, sightseers or plain tourists. Some are hoping for a cure or a miracle. Virtually none of the visitors return home without taking along the supposedly miraculous Lourdes water - in jerrycans, if need be - either for their own benefit or to please others. A generally wellappreciated factor in Lourdes is the pleasurable gathering of kindred souls. This does not just apply for the older people, but perhaps even more for the large numbers of young people, who get together in groups and sing wholeheartedly. Lourdes enables meetings, new friendships and even new loves. Just for a moment, one is free of the pressure to defend or justify oneself, or to feel ashamed in an outside world that is gradually moving away from religion. In this respect, Lourdes can be experienced as a warm bath. Many a pilgrim feels free to openly wear religious symbols, like crucifixes, rosaries, and even habits. All day long, there is a loud resounding of the Ave Maria (Hail Mary), the Salve Regina (Hail Holy Queen) and many other Latin hymns. Lourdes offers a continuous opportunity to join celebrations, masses and processions, in which flags and banners are carried with pride. Only few people will be left utterly untouched by the daily Procession of Mary with the abundance of candles that closes the evening. Perhaps more than a place of miracles, devotion and contemplation, Lourdes is a place of confirmation. The Sanctuary of Lourdes is pervaded with the confirmation that the Catholic faith, with all its dogmas, religious mysteries, traditions and rites, is the only True Faith. The charisma of this holy place does not leave room for doubt. Lourdes allows religious pilgrims and tourists to imagine they are right.

The official bookshop at the Sanctuary does sell the testimonial novel Das Lied von Bernadette and the film The Song of Bernadette (on DVD), but not the critical book Lourdes by Zola, nor the problematizing film Lourdes by Hausner. Monsignor Jacques Perrier, Bishop of Tarbes and Lourdes, was pleased with Une femme nommée Marie by Hossein, but regretted having given permission to film Lourdes by Hausner on location. On reflection afterwards, he condemns the film as "ambigu" and "catastrophique" (Perrier 2011), because it resembles a documentary on the one hand, but on the other contains fictitious elements calling into question the veracity of the miracle. There are more Catholic priests who deem Hausner's film too cold and distant. They 
praise the true atmosphere of love, compassion and solidarity that characterizes Lourdes. I do, incidentally, venture to doubt the obviousness of this atmosphere of compassion in Lourdes, which seems to exist mainly in the eye of the beholder. In the days around the Assumption of Mary 2011, I witnessed the odd compassion and helpfulness, the usual ritual obedience and a great deal of miracle tourism. There is no such thing as an atmosphere of doubt or envy, for that matter. Lourdes is no place for doubt, let alone envy - if only because of the fact that the miracle-to-pilgrim ratio is far too disappointing to arouse anyone's envy. Fact is that a testimonial piece like Une femme nommée Marie fits much better into the religious strategy of Lourdes as a place of

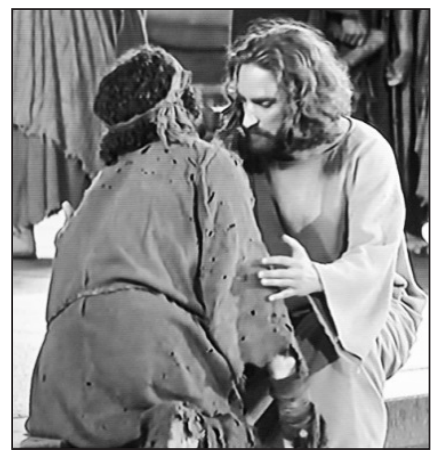

Figure 15. Jesus healing a leper (still from Une femme nommée Marie).

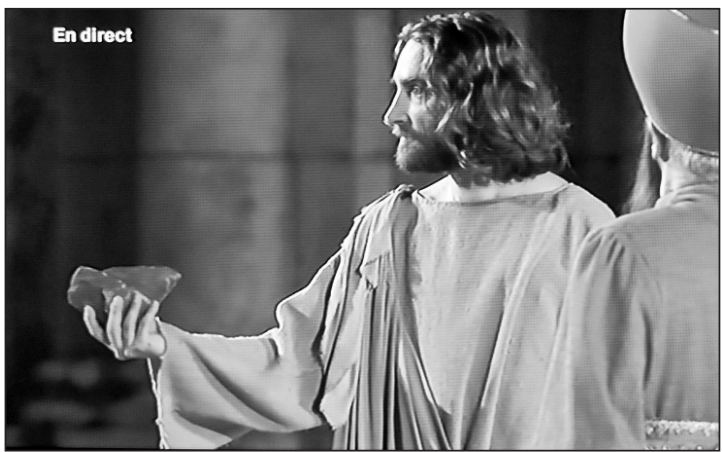

Figure 16. "Let he who is without sin cast the first stone" (still from Une femme nommée Marie). 
pilgrimage with an obvious Catholic and traditional message than Lourdes by Hausner, which is too far out of tune. Significantly, the local cinema of Lourdes has scheduled a daily screening of the film Bernadette by Jean Delannoy, which is faithful to the historical testimonies and events as they were handed down and (consequently) to the traditional Catholic doctrine of the faith.

Robert Hossein's open-air play, which got a rave review in Le Figaro (Tranchant 2011), admits of one interpretation only: the Catholic miracle stories of healing, the attainment of the salvation of the soul through the gospels and the miracle stories about the Marian apparition in Lourdes together constitute the Truth Beyond Doubt. As long as believers keep practising the mercy and charity of Jesus and Mary, all will be well in this evil world and in the Great Beyond. The artistic story presented by Hossein allows one pro-Catholic interpretation of charity only.

Hausner, on the other hand, prefers to refrain from all-explanatory expeditions in her productions. She expects her audience to give their own interpretation to the images and events. More than anything, she wants to emphasize the ambivalence of the miracle and the miraculous place in the film Lourdes (Lourdes, a Film 2009: 15). Hausner sets out to find the prickly edges of the fairy tale: "Lourdes is a [cruel] fairy tale, a day-dream or a nightmare." She points at the unclarity as to when one should merit a miracle: "A miraculous

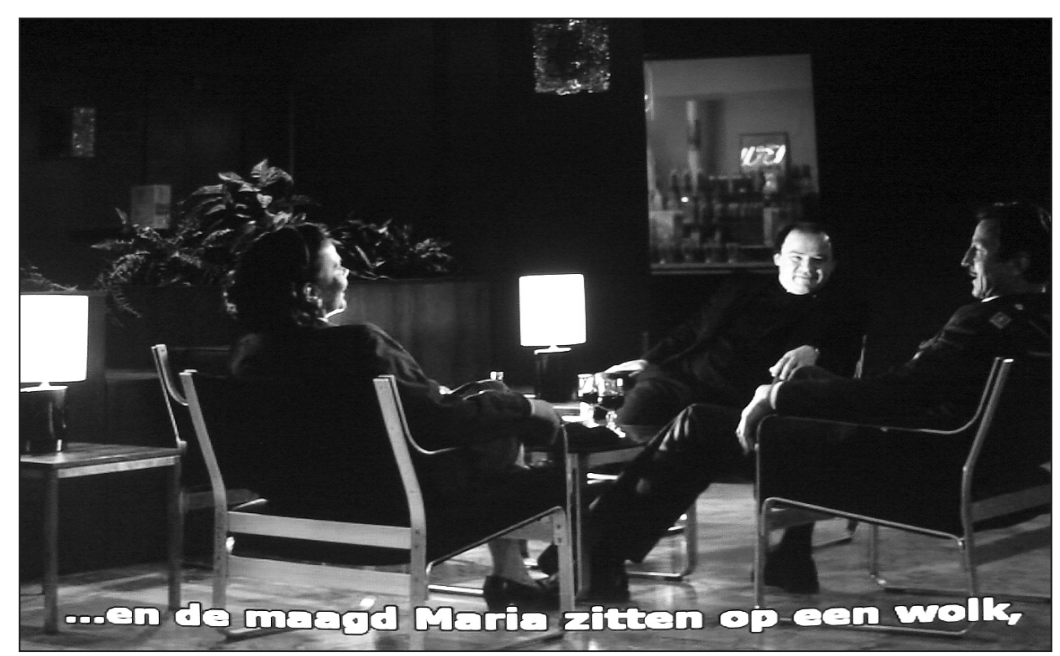

Figure 17. The Officer is telling a joke (still from Lourdes) 
healing is unjust. Why is one person healed and not another? What can one do to be healed? Pray [...]; choose humility [...]; or on the contrary, do nothing, like Christine?" Much seems to depend on coincidence: "One realizes that this 'miracle' doesn't contain a moral or a meaning... that it's perhaps only a coincidence. It's only a temporary stage because nothing is certain."12

All in all, we can conclude that Hossein's story of Lourdes is primarily a hopeful Catholic testimony of the traditional religious truth, in the process offering a solution for some of the problems of today's world. In doing so, Hossein supports a generation of traditional Catholics in particular. Hausner, on the contrary, casts doubt on the unshakeable Catholic truths, thereby supporting a critical generation who believes it remains to be seen if the time-honoured religious stories and doctrines are valid, if miracles really exist and if one ought to believe in supernatural intervention.

So as to put matters into perspective, the film Lourdes by Hausner contains a scene showing an informal chat with an Officer of the Order of Malta telling a joke to a female colleague and a priest:

The Holy Spirit, Jesus and the Virgin Mary are sitting on a cloud, discussing their holiday plans.

The Holy Spirit says: "I've got an idea: let's go to Bethlehem." Jesus says: "Bethlehem? Nah, we've been there so often."

The Holy Spirit starts thinking and says: "Fine. In that case: how about Jerusalem?"

Jesus says: "No, not to Jerusalem. We've been there too often."

The Holy Spirit thinks again and says: "I've got it! Let's go to Lourdes."

The Virgin Mary jumps up and says: "Yeah, great! I've never been there before!"

\section{NOTES}

1 General information about Lourdes was taken from Caujolle 2008, Caspers \& Post 2008, Tervoort 1991, Guigné 2011 and from Wikipedia and IMDb pages about Lourdes, Bernadette Soubirous, literature and film. In the Christian world as a whole, Our Lady of Guadalupe (in the Tepeyac desert, near Mexico City) is the largest place of pilgrimage with twenty million pilgrims per year (Caspers \& Post 2008: 62). In Caspers \& Post 2008: 25-51, there is also more information about the discussion (within and outside the Catholic Church) whether certain places could be allotted a specific kind of sacredness, not to be found elsewhere (the so-called localized cult).

2 The quoted expression was taken from an interview with actor Bruno Todeschini (Lourdes, a Film 2009: 49). This "religious Disneyland judgement" is repeated in several other reviews of the film Lourdes. 
3 See the interview by Dave Calhoun with Jessica Hausner: DC: "So, are you an atheist?" JH: "Well, yes, I would say, yes. [...] Usually I'm an atheist, but sometimes I weaken and become an agnostic." In an interview with Emily Seed, she adds: "I believe that inexplicable healings do exist, and not always in a spiritual context. During my research I spoke to many doctors, who told me that phenomenal healings happen every day in hospitals, which fascinates me. I don't believe in religious miracles, however" (Seed 2010). Talking about the director, actress Elina Löwensohn remarks: "Jessica Hausner is revealing the contradiction between what she experienced in Catholic schools and her rejection of this" (Lourdes, a Film 2009: 45).

4 About the open-air play and Hossein, see: Borde 2011a, Borde 2011b, Evangiles 2011, Guigné 2011, Lebard 2011, Levrault 2011, Servat 2011, Télé Z 2011, Tranchant 2011, Vayne 2011.

5 A French phenomenon: a sound and light show with tableaux vivants, presented at nighttime at an outdoor location near a historical building.

6 About his religious spectacles: Dureau 2008: 104.

7 Hossein 1978: 29: "Mes parents n'attachaient aucune importance à ma formation religieuse." This is not to say that Robert as a child did not cherish any sort of religious sentiment. Hossein 1978: 231-232: "Je suis né croyant sans le savoir." Cf. also Hossein 1981: 226 and 2002: 51-52.

8 Hossein \& Malherbe 2007: 76: "Je me suis fait baptiser en même temps que mon fils. Le père et le fiston dans la flotte. C'est quelque chose de se faire baptiser avec sa progéniture." See also Hossein 1981: 229-230 and Barthélémy 1987: 33.

9 "Ordet" means "The Word". This solemn black-and-white film is about a Danish Protestant rural family, threatening to collapse under religious disagreements, but subsequently confronted with a miracle bringing people back together: the daughter-in-law, who had died in childbirth, comes back to life while on the bier, when her religious maniac brother-in-law summons her to get up.

${ }^{10}$ According to Bernadette Soubirous, the Virgin Mary always smiled at her.

${ }^{11}$ See, for example, Catholic Commentary 2009 and Hanvey SJ 2009. By contrast, the American Jesuit James Martin 2010 is very positive.

${ }^{12}$ For the quotations, see Lourdes, a Film 2009: 8, 11 and 20 (in respective order).

\section{REFERENCES}

Barthélémy, Cécile 1987. Robert Hossein. Lausanne: Pierre Marcel Favre.

Borde, Jean-Christophe 2011a. Une femme nommée Marie. Lourdes magazine, édition spéciale Spectacle Robert Hossein 183, pp. 2-4.

Borde, Jean-Christophe 2011b. "J'ai eu à Lourdes une rélévation" Robert Hossein présente Une femme nommée Marie. Lourdes magazine 183 (July-August), pp. $4-5$. 
Caspers, Charles \& Post, Paul (eds.) 2008. Wonderlijke ontmoetingen... Lourdes als moderne bedevaartplaats. [Miraculous Meetings... Lourdes as a Modern Place of Pilgrimage.] Heeswijk: Uitgeverij Abdij van Berne.

Caujolle, Marie 2008. Lourdes: verschijningen, boodschap, bedevaart. [Lourdes: Apparitions, Message, Pilgrimage.] Vic-en-Bigorre Cedex: MSM.

Dureau, Christian 2008. Robert Hossein est son nom. Paris: D. Carpentier.

Evangiles 2011 = Evangiles vues par Robert Hossein à Lourdes, une sobre fresque, Les. Direct Matin, 13-8-2011.

Guigné, Anne de 2011. Lourdes tributaire des dons des pélerins. Le Figaro 17-8-2011, p. 23.

Hossein, Robert 1978. La sentinelle aveugle. Paris: B. Grasset.

Hossein, Robert 1981. Nomade sans tribu. Paris: Fayard.

Hossein, Robert 2002. Lumière \& ténèbres. Paris: Le Pré aux Clercs.

Hossein, Robert \& Delphine de Malherbe 2007. N'ayez pas peur... de croire. Paris: J.-C. Lattès.

Lebard, Joséphine 2011. Robert Hossein: "Nous avons le pouvoir d'aimer". Pélerin 6715 (11-8-2011), pp. 4-7.

Levrault, Gérald 2011. Nouvelle fresque. Télé Z (13-19 August 2011), p. 4

Lourdes, a Film by Jessica Hausner 2009 . (Information leaflet for the press, also available at: http://www.coop99.at/www-LOURDES/en/press.htm; last viewed 24-8-2011). Paris.

Servat, Henry-Jean 2011. Robert Hossein salue Marie. Le Journal du Dimanche, 7-82011, p. 26.

Télé Z 2011. Une femme nommée Marie. Télé Z (13-19 August 2011), p. 19.

Tervoort, Frans 1991. Gesprekken over Lourdes. [Talking about Lourdes.] Schoorl: Den Haag.

Vayne, François 2011. “Aimer, aider, partager... avant qu'il ne soit trop tard”. Lourdes magazine, édition spéciale Spectacle Robert Hossein, 183, p. 1.

\section{FILMS AND PERFORMANCES}

Delannoy, Jean: Bernadette (1988, [multiple] daily screening of the film at Cinéma Bernadette, Lourdes).

Dreyer, Carl Theodor: Ordet (1955, DVD).

Hausner, Jessica: Hotel (2004, DVD).

Hausner, Jessica: Lourdes (2009, DVD).

Hossein, Robert: L'affaire Dominici (2010, Théâtre de Paris).

Hossein, Robert: Une femme nommée Marie (Lourdes, 13 August 2011).

King, Henry: The Song of Bernadette (1943, DVD). 


\section{INTERNET SOURCES}

All last viewed 24-8-2011.

Calhoun, Dave: 'Jessica Hausner on Lourdes'. Timeout London: http://www.timeout.com/ film/features/show-feature/9751/Jessica_Hausner_on- Lourdes-.html

Catholic Commentary 2009. Jessica Hausner's Lourdes. http://rccommentary2.blogspot. com/2009/10/jessica-hausners-lourdes.html

Film forum: 'ourdes 2009. Timeout London: http://www.timeout.com/film/reviews/87794/ lourdes.html

Hanvey, S. J. 2009. James: 'Lourdes'. Thinking Faith, the Online Journal of the British Jesuits: http://www.thinkingfaith.org/articles/FILM_20091023_4.htm

IMDb (Internet Movie Database): http://www.imdb.com/

Martin, S. J. 2010. James: Lourdes: a new Movie. America; the National Catholic Weekly. http://www.americamagazine.org/blog/entry.cfm?id=38780534-3048741E-1848047830937398

Lourdes, a Film by Jessica Hausner 2009. http://www.coop99.at/www-LOURDES/ en/index.htm

Perrier 2011. Film "Lourdes" de Jessica Hausner: un film "catastrophique" selon Mgr Perrier. http://www.youtube.com/watch?v=BmdB4BRahF8

Romney, Jonathan 2010. Lourdes, Jessica Hausner, 99 mins, (U). The Independent Reviews: http://www.independent.co.uk/arts-entertainment/films/reviews/lourdesjessica-hausner-99-mins-u-1929134.html

Seed, Emily 2010. Lourdes: An Interview with Jessica Hausner. BEV News: http://www.birds-eye-view.co.uk/news/2010/01/29/lourdes-an-interview-withjessica-hausner/

Tranchant, Marie-Noëlle 2011. Une femme nommée Marie, le nouveau Robert Hossein. Le Figaro 14-8-2011.

http://www.lefigaro.fr/culture/2011/08/14/03004-20110814ARTFIG00133--unefemme-nommee-marie-le-nouveau-robert-hossein.php

Wikipedia Bernadette: http://en.wikipedia.org/wiki/Bernadette_Soubirous

Wikipedia Lourdes: http://en.wikipedia.org/wiki/Lourdes 